\title{
Effect of bosentan on the production of proinflammatory cytokines in a rat model of emphysema
}

\author{
Gamze Kırkı1 ${ }^{1,4}$, Mehmet Hamdi Muz', \\ Figen Deveci ${ }^{1}$, Teyfik Turgut', \\ Fulya İlhan ${ }^{2}$ and İbrahim Özercan ${ }^{3}$ \\ ${ }^{1}$ Department of Chest Disease \\ 2Department of Immunology \\ ${ }^{3}$ Department of Pathology \\ Firat University, Faculty of Medicine \\ Elazig 23200, Turkey \\ ${ }^{4}$ Corresponding author: Tel, 90-424-2333555-2860 \\ Fax: 90-424-2388096; E-mail, gamkirkil@yahoo.com
}

Accepted 1 August 2007

Abbreviations: AM, alveolar macrophages; BALF, bronchoalveolar lavage fluid; COPD, chronic obstructive pulmonary disease; ET, endothelin; i.t., intratracheally; NAC, N-acetylcysteine; NG, neutrophil granulocyte; PMN, polymorphonuclear cells; PPE, porcine pancreatic elastase

\begin{abstract}
Endothelin (ET) receptor antagonists have been developed to produce a reduction of ET related effects in various diseases, as well as in animal models of airway inflammation. We aimed to investigate the anti-inflammatory potential of bosentan on a rat model of emphysema. Thirty Wistar male rats were classified as control group (group 1), intratracheally (i.t.) instilled with saline, treated with vehicle solution; elastase group (group 2), i.t. instilled with porcine pancreatic elastase (PPE), treated with vehicle solution; and PPE+bosentan group (group 3), i.t. instilled with PPE, treated with bosentan. The levels of TNF- $\alpha$, IL-1 $\beta$, IL- 6 , and IL-8 in bronchoalveolar lavage fluid (BALF) and lung tissue, cell counts in BALF, and histologic analysis of all groups were evaluated. Neutrophile granulocytes (NG) and alveolar macrophages (AM) were increased more in group 2 than in group $1(P<0.001, P$ $=0.04$, respectively). Compared with group 2 , neutrophil granulocyte (NG) and alveolar macrophages (AM) counts were decreased in group $3(P<0.001)$. Histological examination confirmed a diffuse neutrophilic inflammation and irregular alveolar air space enlargement in group 2. Treatment with bosentan partially reduced the enlarged lung volumes. Compared with group 1, the BALF levels of TNF- $\alpha$ and IL-6, and
\end{abstract}

the lung tissue levels of IL-1 $\beta$, IL-6, and IL-8 were increased in group $2(P=0.028, P=0.005, P=0.001, P=$ $0.019, P<0.001$, respectively). The TNF- $\alpha$ and IL-8 levels of $\operatorname{BALF}(P=0.007, P=0.001$, respectively), and the TNF- $\alpha$, IL-1 $\beta$, IL- 6 , and the IL-8 levels of lung tissue $(P=0.031, P=0.017, P=0.007, P<0.001)$ were decreased in group 3 compared to group 2 . In conclusion, bosentan decreased the inflammatory response by reducing numbers of inflammatory cells and proinflammatory cytokines.

Keywords: bosentan; endothelins; pulmonary emphysema; receptors, endothelin

\section{Introduction}

Elastase is an important inducer of lung inflammation. The inflammatory response triggered by elastase is characterized by neutrophil and macrophage recruitment, which is still present after one month (Finlay et al., 1996). These cells could be the source of proteases and oxidants that contribute to the destruction of lung connective tissue, as well as of inflammatory mediators that exacerbate elastase-induced emphysema (Lucey et al., 2002). Furthermore, elastase provokes a disruption of the alveolar cell walls that leads to enlargement of the airspace regularly distributed throughout the parenchyma (Rubio et al., 1998).

Endothelin-1 (ET-1) has been identified as important in inflammatory lung disorders (Springall et al., 1991; Giaid et al., 1993; Langleben et al., 1993). ET-1 is raised in the airways of asthmatic subjects and has been shown to stimulate mucus secretion, airway oedema, smooth muscle mitogenesis, and also bronchial hyperresponsiveness (Hay, 1999). It is also thought to have important proinflammatory effects in the airways, being both a chemoattractant mediator, such as the IL-6 and IL-8, and a GM-CSF (Mullol et al., 1996). Endothelin receptor antagonists have been developed that produce a significant reduction in ET related effects in various diseases, as well as in animal models of airway inflammation. Thus, they might provide an effective treatment for emphysema (Finsnes et al., 1997).

We aimed to investigate the anti-inflammatory potential of bosentan, a nonpeptide compound with mixed antagonist properties for $E T_{A}$ and $E T_{B}$ 
receptors, via examination of the cytokine levels TNF- $\alpha$, IL-1 $\beta$, IL-6, and IL-8 in bronchoalveolar lavage fluid (BALF) and in the lung tissue of the established rat model of emphysema.

\section{Materials and Methods}

\section{Drugs}

Animals were instilled with 0.2 IU porcine pancreatic elastase (PPE) (Sigma Inc., St. Louis, MO) $\mathrm{g}^{-1}$ of body weight in $0.5 \mathrm{ml}$ of saline. Bosentan, an orally active nonpeptide endothelin antagonist (Actelion, Allschwil, Switzerland) was suspended in $5 \%$ gummi arabicum to a concentration of $30 \mathrm{mg} /$ $\mathrm{ml}$. The vehicle solution consisted of $5 \%$ gummi arabicum. Dilutions were prepared daily before administration.

\section{Animals}

Thirty male Wistar rats aged 11 wk with an average weight of $300 \mathrm{~g}$ were provided by the Experimental Animal Center, Firat University Medicine School. All studies were performed with the approval of the experimental animal committee of the university.

\section{Study design}

A total of 30 animals were classified into the following three groups:

Control group (group 1, $n=10$ ) i.t. instilled with saline solution and treated with vehicle solution (5\% Gummi arabicum) via an orogastric tube $1 \mathrm{~h}$ before i.t. saline instillation for 15 days.

Elastase group (group 2, $n=10$ ) i.t. instilled with 0.2 IU porcine pancreatic elastase (PPE). $\mathrm{g}^{-1}$ of body weight in $0.5 \mathrm{ml}$ saline and treated with vehicle solution ( $5 \%$ Gummi arabicum) via an orogastric tube $1 \mathrm{~h}$ before i.t. elastase instillation for 15 days (van de Lest et al., 1995).

Elastase+bosentan group (group 3, $n=10$ ) i.t. instilled with 0.2 IU PPE.g ${ }^{-1}$ of body weight in 0.5 $\mathrm{ml}$ saline and treated with bosentan $(100 \mathrm{mg} / \mathrm{kg} / \mathrm{d})$ via an orogastric tube $1 \mathrm{~h}$ before i.t. elastase instillation for 15 days.

\section{Bronchoalveolar lavage}

On the 16th day, the animals were anesthetized with ketamin $(100 \mathrm{mg} / \mathrm{kg})$ and sacrificed. BALF was handled as previously described (Wang et al., 2003). Bronchoalveolar lavage (BAL) was performed by flushing the airways with $5 \mathrm{ml}$ of saline through the tracheal cannula three times. Bronchoalveolar lavage fluid (BALF) was pooled and centri- fuged at 1,500 rpm for $5 \mathrm{~min}$. The supernatant was harvested for cytokine analysis and the pellet was smeared onto slides for cell classification and counting in BALF. After the cell smear was stained with Wright-Giemsa, the white cell count, neutrophil granulocytes (NG), and alveolar macrophages (AM) were measured by counting 200 cells under light microscopy.

\section{Histologic analysis of the lung}

Lungs were fixed in $10 \%$ formaldehyde. After embedding in paraffin, the tissues were cut into 5 $\mu \mathrm{m}$ sections and stained with hematoxylin-eosin methods and assessed under a light microscope (Finsnes et al., 2000).

\section{Cytokine analysis in BALF and lung tissue}

Lung tissue was weighed (for $1 \mathrm{~g}$ tissue, $19 \mathrm{ml}$ PBS; $\mathrm{pH}: 7.4)$ and homogenized using an Ultra Turrax T25 basic homogenizer (IKA Labortechnic, Janke and Kunkel GmBH, Co. Germany) $(4,000 \times$ $g$ for $10 \mathrm{~min})$. Prepared lung tissue homogenates, and BALF samples were centrifuged $(4,000 \times g$, $10 \mathrm{~min})$, and supernatants were separeted. The levels of TNF- $\alpha$, IL-1 $\beta$, IL- 6 , and IL- 8 in BALF, and the lung tissue of the three groups were measured using commercially available ELISA kits (MedSystems Diagnostics Gmbh, Vienna, Austria) according to the manufacturer protocols.

\section{Statistical analysis}

Data are expressed as mean \pm SE. The nonparametric Kruskal-Wallis test was used. Comparisons between groups were performed using the Mann-Whitney Rank Sum test. A $P$ value $<0.05$ denotes the presence of a significant statistical difference.

\section{Results}

\section{Cell profile in BALF}

NG and $A M$ counts in rat BALF for each group are shown in Table 1. The percentage of NG and AM was significantly increased in group 2 when compared with group $1(P<0.001, P=0.04$, respectively), and significantly decreased in group 3 when compared with group $2(P<0.001)$.

\section{Cytokine levels in BALF and lung tissue}

The cytokine levels in rat BALF and lung tissue of each group are shown in Figures 1 and 2. 
Compared with group 1, the levels of TNF- $\alpha$, $\mathrm{IL}-1 \beta, \mathrm{IL}-6$, and IL-8 in BALF and lung tissue were all increased in group 2, but statistical significance occured only in BALF levels of TNF- $\alpha$, and IL-6,

Table 1. The count of neutrophil granulocytes and alveolar macrophages in rat BALF of each group.

\begin{tabular}{ccc}
\hline \multirow{2}{*}{ Group } & \multicolumn{2}{c}{ Cell classification/\% } \\
\cline { 2 - 3 } & $\begin{array}{c}\text { Neutrophil } \\
\text { granulocytes }\end{array}$ & $\begin{array}{c}\text { Alveolar } \\
\text { macrophages }\end{array}$ \\
\hline Group 1 & $5.06 \pm 1.66$ & $59.53 \pm 2.58$ \\
Group 2 & $17.95 \pm 1.48^{\star}$ & $62.78 \pm 3.45^{\star}$ \\
Group 3 & $12.20 \pm 1.26^{\dagger}$ & $44.70 \pm 4.21^{\dagger}$ \\
\hline
\end{tabular}

${ }^{*} P<0.05$ when compared with group 1

${ }^{\dagger} P<0.05$ when compared with group 2

A

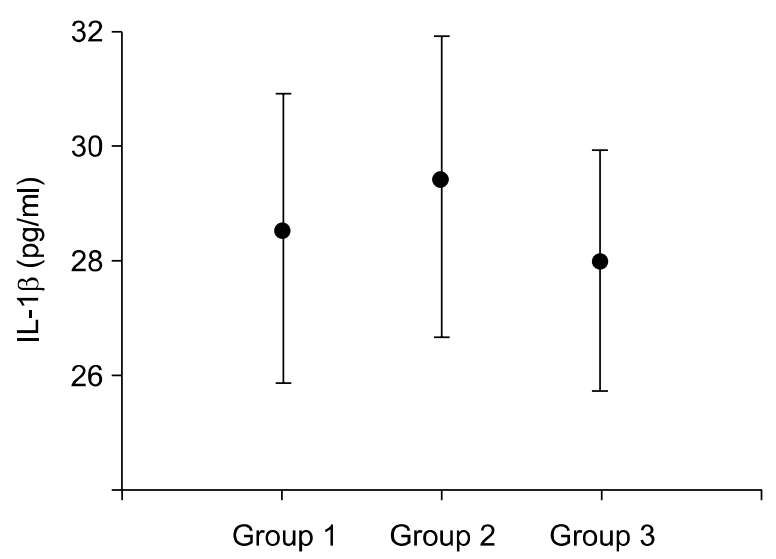

C

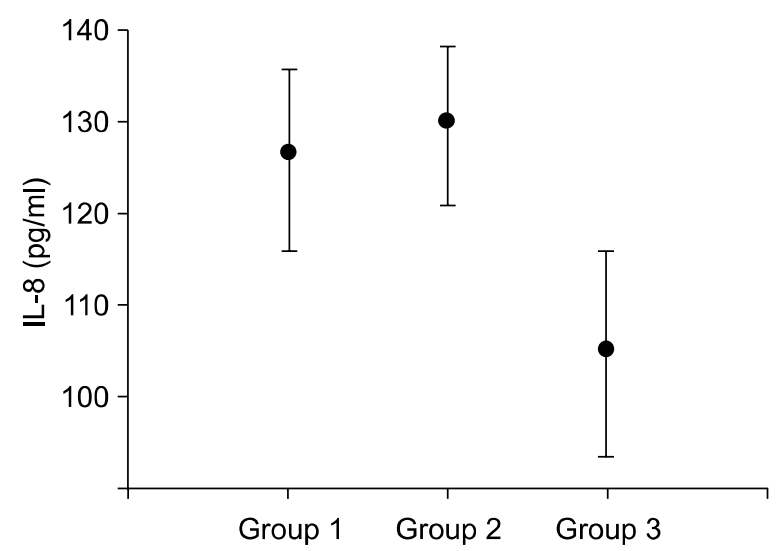

lung tissue levels of IL-1 $\beta, \mathrm{IL}-6$, and IL-8 $(P=$ $0.028, P=0.005, P=0.001, P=0.019, P<0.001$, respectively).

The cytokine levels were decreased in group 3 compared to group 2, but statistical significance occured in TNF- $\alpha$, the IL-8 levels of BALF ( $P=$ $0.007, P=0.001$, respectively), and TNF- $\alpha, \mathrm{IL}-1 \beta$, IL-6, and IL-8 levels of lung tissue $(P=0.031, P=$ $0.017, P=0.007, P<0.001)$. When group 1 was compared with group 3 , only the IL-8 levels of BALF decreased significantly in group $3(P=$ 0.005).

\section{Histological examination of lung tissues}

The histological apperance of the control group is shown in Figure 3. Histological examination of lung tissues confirmed a diffuse neutrophilic inflammation with oedema in the emphysema group. Elastase instillation caused irregular alveolar air space

B

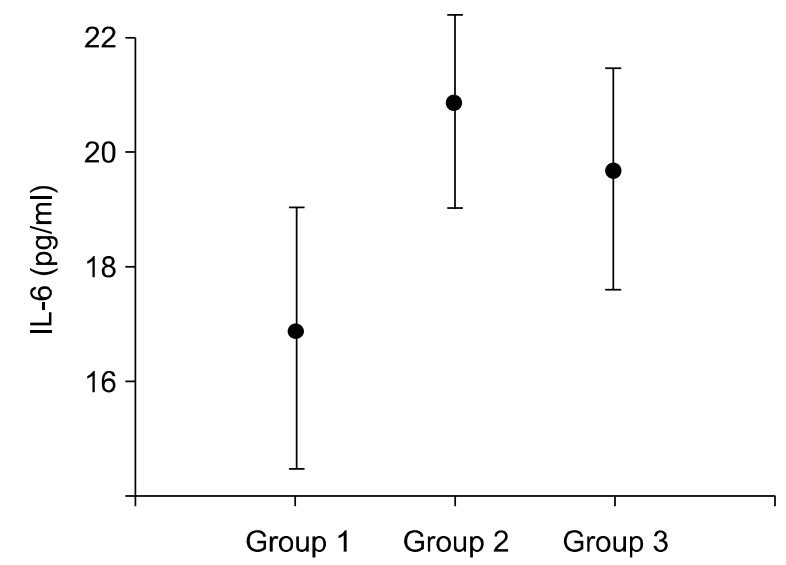

D

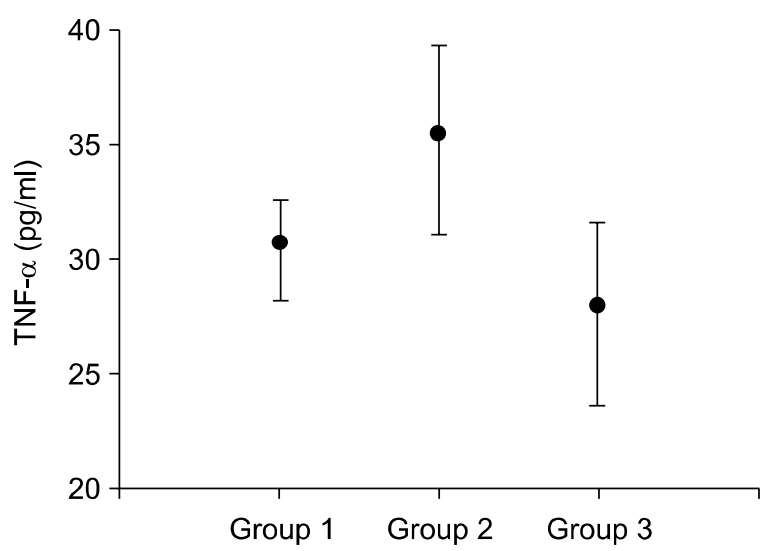

Figure 1. Concentration of proinflammatory mediators in bronchoalveolar lavage fluid. (A) IL-1 $\beta$, (B) IL-6, (C) IL-8, (D) TNF- $\alpha$. Error bars show $95.0 \%$ Cl of mean. 
A

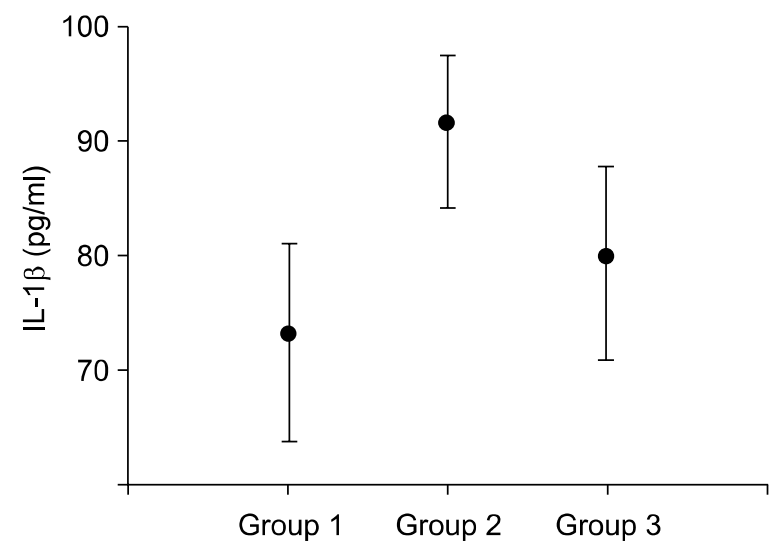

C

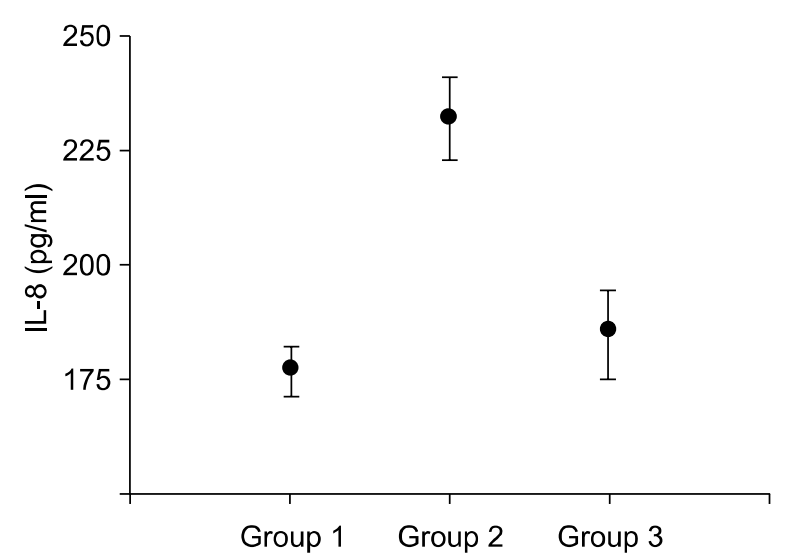

B

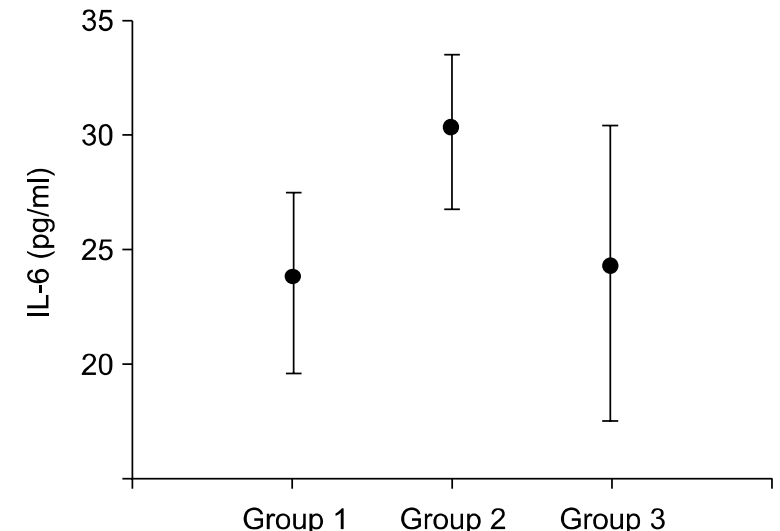

D

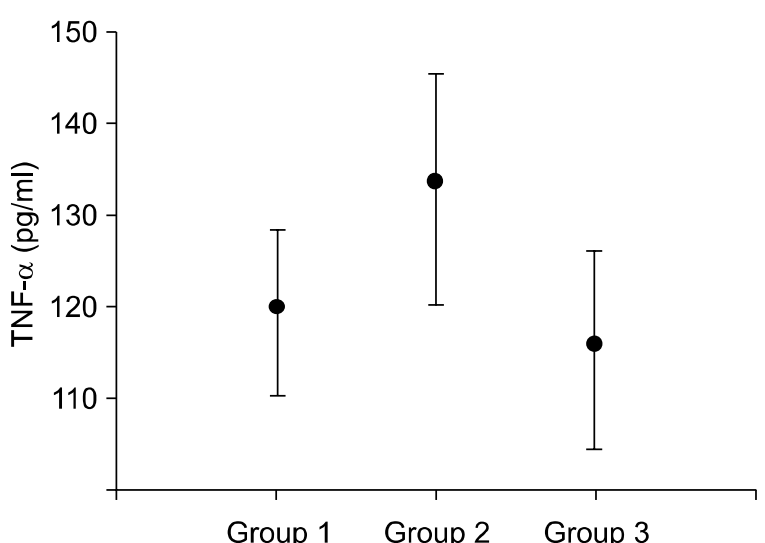

Figure 2. Concentration of proinflammatory mediators in lung tissue. (A) IL-1 $\beta$, (B) IL-6, (C) IL-8, (D) TNF- $\alpha$. Error bars show $95.0 \% \mathrm{Cl}$ of mean.

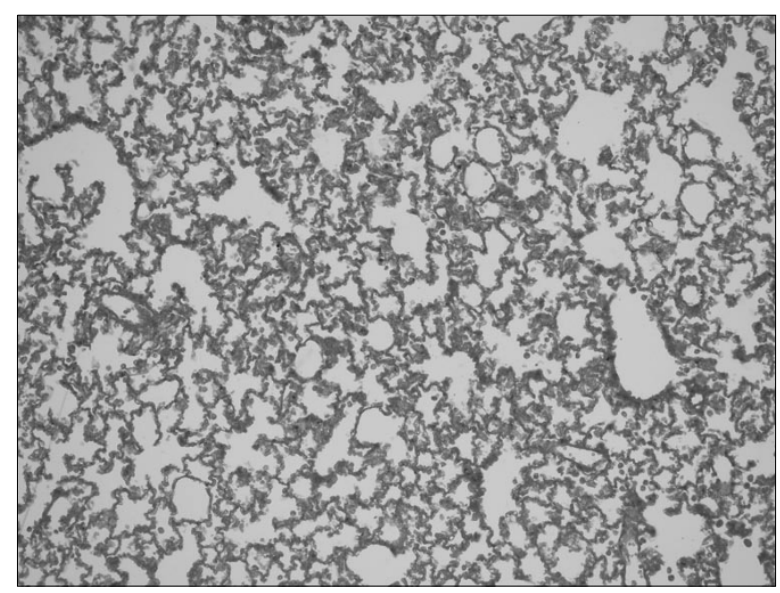

Figure 3. Histological apperance of the control group. Hematoxylin-eosin $\times 200$.

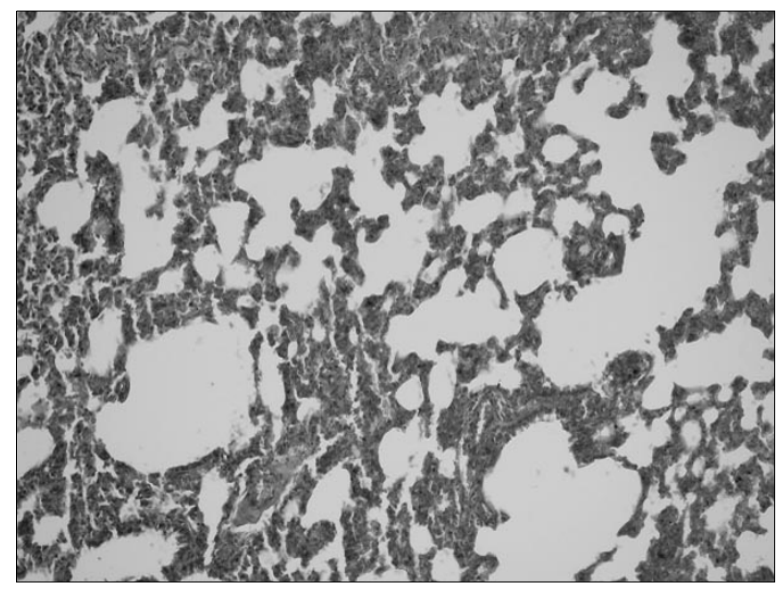

Figure 4. Diffuse neutrophilic inflammation with oedema in the emphysema group. Elastase instillation caused increased lung volumes, irregular alveolar air space enlargement, fragmentation, and attenuation of alveolar septa. Hematoxylin-eosin $\times 200$. 


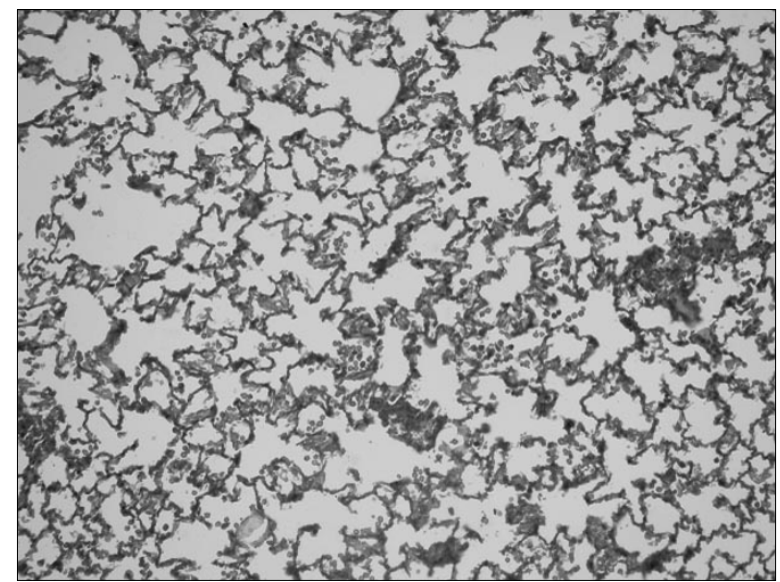

Figure 5. Treatment with bosentan partially reduced the enlarged lung volumes, decreased the neutrophilic inflammation, and no oedema was observed. Hematoxylin-eosin $\times 200$.

enlargement, fragmentation, and attenuation of alveolar septa (Figure 4). Lesions involving the lung parenchyma distal to the terminal bronchioles were observed and possesed features resembling panlobular and centrilobular emphysema. Treatment with bosentan partially reduced the enlarged lung volumes and decreased the neutrophilic inflammation associated with this emphysema model, and no oedema was observed (Figure 5).

\section{Discussion}

Although the exact pathologic mechanism is unclear, the infiltration and activation of neutrophils and $\mathrm{AM}$, the predominant inflammatory cells in airways, as well as the release of inflammatory cytokines, are believed to play a central role in the pathophysiology of chronic obstructive pulmonary disease (COPD) (Chung, 2001). It is known that intratracheal elastase instillation induces an early inflammatory response with neutrophils and macrophages that is still present after one month (Finlay et al., 1996). In the study of van de Lest (van de Lest et al., 1995), infiltration of inflammatory cells into the lung $3 \mathrm{~h}$ after intratracheal instillation of porcine pancreatic elastase was observed. The first emphysematous lesions were noted 2 weeks after elastase treatment. On the contrary, no evidence showing that elastase-induced emphysema is accompained by an increase in the number of polymorphonuclear cells (PMN) was shown in the work of Cantor et al. (1998). They found that one week after induction of lesions with elastase, the number of PMNs was normal. In our study, we determined that the percentage of neutrophile granulocytes and AM significantly increased 2 wks after elastase instillation and, after bosentan treatment, the percentage significantly decreased. In a study that evaluated the effect of antioxidant $\mathrm{N}$-acetylcysteine (NAC) in a rat model of elastaseinduced emphysema, it was found that treatment with oral NAC partially attenuated lung emphysema, possibly due to the anti-inflammatory effect of NAC throughout the diminution of PMN influx into the lung (Rubio et al., 2004).

It is known that the circulating levels of ET-1 increased in patients with emphysema, and endothelins act as proinflammatory agents (Yamakami et al., 1997). In vitro, ET-1 has been shown to stimulate the release of the cytokines TNF- $\alpha$, IL-1 $\beta$, IL-6, and IL-8 (Helset et al., 1993; Huribal et al., 1994), and a study showed that ET-1 antagonism strongly inhibited the production of these cytokines within the airways (Finsnes et al., 2001). IL-1 $\beta$ has been implicated in the migration of inflammatory cells in BALF of symptomatic asthmatic patients (Broide et al., 1992). In vitro studies have shown that IL-1 $\beta$ increases ET-1 release from cultured airway epithelial cells (Nakano et al., 1994), and, conversely, IL-1 $\beta$ is found to be produced by ET-1 stimulation of human macrophages (Helset et al., 1993). Over the last years, TNF- $\alpha$ has gained attention as an important mediator in inflammatory disorders, such as asthma (Kips et al., 1993), and it should be noted that the synthesis of TNF- $\alpha$ is preceded by the syntesis of ET-1 (Finsnes et al., 2001). Lucey et al. (2002) recently stated that TNF- $\alpha$ and IL-1 $\beta$ account for approximately $80 \%$ of the emphysema that develops after elastase treatment, pointing out that these proinflammatory mediators are taking part in the development of the lesion. IL-6 is an other cytokine that plays a pivotal role in chronic airway inflammation and structural remodeling (Wang et al., 2003). IL-8 is also an important mediator that promotes the migration of neutrophils (Blackwell et al., 1994) and eosinophils (Erger and Casale, 1995) from the circulation to the inflammatory site.

Our study revealed that the levels of TNF- $\alpha$, $\mathrm{IL}-1 \beta, \mathrm{IL}-6$, and IL-8 in lung tissue, and in BALF as well as neutrophils and AM in the BALF in emphysema group treated with bosentan were decreased compared to the levels in emphysema. Thus, bosentan probably inhibits airway inflammation in emphysema via blocking various agents in the inflammatory network.

Bosentan is a highly specific endothelin antagonist and has not been shown to directly affect other mediators (Clozel et al., 1994). It has been shown that treatment of animals with bosentan 
resulted in a substantial decrease in BALF concentrations of several proinflammatory mediators considered to be of importance in bronchial asthma, including TNF- $\alpha$, IL-1 $\beta$, IL-4, and ET-1 (Finsnes et al., 1997). This observation provides insight into the mechanism of bosentan as an inhibitor of the inflammatory reaction. In a murine model of inflammatory bowel disease, the antiinflammatory effect of bosentan was investigated, and it was determined that bosentan reduced inflammation in this animal model (Anthoni et al., 2006). In another study, it was seen that prophylactic oral administration of bosentan reduced clinical inflammation in trinitrobenzene sulphonateinduced colitis in rats (Güllüoglu et al., 1999).

To our knowledge, this is the first study to report an anti-inflammatory effect for bosentan in the endothelin receptor antagonism in airway inflammation, indicating that bosentan has potential for treatment of neutrophilic airway inflammation, such as emphysema.We conclude that treatment with bosentan can decrease the inflammatory response by reducing the numbers of inflammatory cells and proinflammatory cytokines.

\section{References}

Anthoni C, Mennigen RB, Rijcken EJ, Laukötter MG, Spiegel HU, Senninger N, Schürmann G, Krieglstein CF. bosentan, an endothelin receptor antagonist, reduces leucocyte adhesion and inflammation in a murine model of inflammatory bowel disease. Int $\mathrm{J}$ Colorectal Dis 2006;21: 409-18

Blackwell TS, Holden EP, Blackwell TR, DeLarco JE, Christman JW. Cytokine-induced neutrophil chemoattractant mediates neutrophilic alveolitis in rats: association with nuclear factor kapa B activation. Am J Respir Cell Mol Biol 1994;11:464-72

Broide DH, Lotz M, Cuomo AJ, Coburn DA, Federman EC, Wasserman SI. Cytokines in symptomatic asthma airways. J Allergy Clin Immunol 1992;89:958-67

Cantor JO, Cerreta JM, Armand G, Turino GM. Aerosolized hyaluronic acid decreases alveolar injury induced by human neutrophil elastase. Proc Soc Exp Biol Med 1998;217:471-5

Chung KF. Cytokines in chronic obstructive pulmonary disease. Eur Respir J 2001;34:50-9

Clozel M, Breu V, Gray GA, Kalina B, Löffler BM, Burri K, Cassal JM, Hirth G, Müller M, Neidhart W, et al. Pharmacological characterization of bosentan, a new potent orally active endothelin receptor antagonist. J Pharmacol Exp Ther 1994;270:228-35

Erger RA, Casale TB. Interleukin-8 is a potent mediator of eosinophil chemotaxis through endothelium and epithelium. Am J Physiol 1995;268:L117-22

Finlay GA, O'Donnell M, O'Connor CM, Hayes JP, FitzGerald
MX. Elastin and collagen remodeling in emphysema: a scanning electron microscopy study. Am J Pathol 1996;149:1405-15

Finsnes F, Skjonsberg OH, Tonnessen T, Naess O, Lyberg T, Christensen G. Endothelin production and effects of endothelin antagonism during experimental airway inflammation. Am J Respir Crit Care Med 1997;155:1404-12

Finsnes F, Skjonsberg OH, Lyberg T, Christensen G. Endothelin-1 production is associated with eosinophilic rather than neutrophilic airway inflammation. Eur Respir J 2000;15:743-50

Finsnes F, Lyberg T, Christensen G, Skjonsberg OH. Effect of endothelin antagonism on the production of cytokines in eosinophilic airway inflammation. Am J Physiol Lung Cell Mol Physiol 2001;280:659-65

Giaid A, Michel RP, Stewart DJ, Sheppard M, Corrin B, Hamid Q. Expression of endothelin-1 in lungs of patients with cryptogenic fibrosing alveolitis. Lancet 1993;341:1550-4

Güllüoglu BM, Kurtel H, Güllüoglu MG, Yegen C, Aktan AÖ, Dizdaroglu F, Yalin R, Yegen BC. Role of endothelins in trinitrobenzene sulfonic acid-induced colitis in rats. Digestion 1999;60:484-92

Hay DW. Putative mediator role of endothelin-1 in asthma and other lung diseases. Clin Exp Pharmacol Physiol 1999;26:168-71

Helset E, Sildnes T, Seljelid R, Konopski ZS. Endothelin-1 stimulates human monocytes in vitro to release TNF- $\alpha$, IL-1 $\beta$, and IL-6. Mediators Inflamm 1993;2:417-22

Huribal M, Kumar R, Cunningham ME, Sumpio BE, McMillen MA. Endothelin-stimulated monocyte supernatants enhance neutrophil superoxide production. Shock 1994;1: 184-7

Kips JC, Tavernier JH, Joos GF, Peleman RA, Pauwels RA. The potential role of tumuor necrosis factor alpha in asthma. Clin Exp Allergy 1993;23:247-50

Langleben D, DeMarchie M, Laporta D, Spanier AH, Schlesinger RD, Stewart DJ. Endothelin-1 in acute lung injury and the adult respiratory distress syndrome. Am Rev Respir Dis 1993;148:1646-50

Lucey EC, Keane J, Kuang PP, Snider GL, Goldstein RH. Severity of elastase-induced emphysema is decreased in tumor necrosis factor- $\alpha$ and interleukin- $1 \beta$ receptor-deficient mice. Lab Invest 2002;82:79-85

Mullol J, Baraniuk JN, Logun C, Benfield T, Picado C, Shelhamer JH. Endothelin-1 induces GM-CSF, IL-6 and IL-8 but not G-CSF release from a human bronchial epithelial cell line (BEAS-2B). Neuropeptides 1996;30:551-6

Nakano J, Takizawa H, Ohtoshi T, Shoji S, Yamaguchi M, Ishii A, Yanagisawa M, Ito K. Endotoxin and pro-inflammatory cytokines stimulate endothelin-1 expression and release by airway epithelial cells. Clin Exp Allergy 1994;24:330-6

Rubio ML, Sanchez-Cifuentes MV, Peces-Barba G, Verbanck S, Paiva M, Gonzalez Mangado N. Intrapulmonary gas mixing in panacinar and centriacinar induced emphysema in rats. Am J Respir Crit Care Med 1998;157: 237-45 
Rubio ML, Martin Mosquero MC, Ortega M, Peces-Barba G, Gonzalez-Mangado N. Oral N-acetylcysteine attenuates elastase-induced pulmonary emphysema in rats. Chest 2004;125:1500-6

Springall DR, Howarth PH, Counihan H, Djukanovic R, Holgate ST, Polak JM. Endothelin immunoreactivity of airway epithelium in asthmatic patients. Lancet 1991;337:697-701

van de Lest $\mathrm{CH}$, Versteeg EMM, Veerkamp $\mathrm{JH}$, van Kuppevelt TH. Digestion of proteoglycans in porcine pancreatic elastase-induced emphysema in rats. Eur Respir

\section{J 1995;8:238-45}

Wang YH, Bai CX, Hong QY, Chen J. Anti-inflammatory effect of methoxyphenamine compound in rat model of chronic obstructive pulmonary disease. Acta Pharmacol Sin 2003; 24:1324-7

Yamakami T, Taguchi O, Gabazza EC, Yoshida M, Kobayashi T, Kobayashi H, Yasui H, Ibata H, Adachi Y. Arterial endothelin-1 level in pulmonary emphysema and interstitial lung disease. Relation with pulmonary hypertension during exercise. Eur Respir J 1997;10:2055-60 